\title{
Archaeological Monitoring for the Casa Rio Restaurant Expansion, San Antonio, Bexar County, Texas
}

I. Waynne Cox

Center for Archaeological Research

Follow this and additional works at: https://scholarworks.sfasu.edu/ita

Part of the American Material Culture Commons, Archaeological Anthropology Commons, Environmental Studies Commons, Other American Studies Commons, Other Arts and Humanities Commons, Other History of Art, Architecture, and Archaeology Commons, and the United States History Commons

Tell us how this article helped you.

This Article is brought to you for free and open access by the Center for Regional Heritage Research at SFA ScholarWorks. It has been accepted for inclusion in Index of Texas Archaeology: Open Access Gray Literature from the Lone Star State by an authorized editor of SFA ScholarWorks. For more information, please contact cdsscholarworks@sfasu.edu. 


\section{Archaeological Monitoring for the Casa Rio Restaurant Expansion, San Antonio, Bexar County, Texas}

\section{Creative Commons License}

\section{(c) (1) \&}

This work is licensed under a Creative Commons Attribution-NonCommercial 4.0 International License 
ARCHAEOLOGICAL MONITORING FOR

THE CASA RIO RESTAURANT EXPANSION

SAN ANTONIO, BEXAR COUNTY, TEXAS

I. Waynne Cox

Center for Archaeological Research

The University of Texas at San Antonio

Archaeological Survey Report, No. 213

1992 



\section{ARCHAEOLOGICAL MONITORING FOR THE CASA RIO RESTAURANT EXPANSION SAN ANTONIO, BEXAR COUNTY, TEXAS}

I. Waynne Cox

Center for Archaeological Research The University of Texas at San Antonio ${ }^{(1)}$ Archaeological Survey Report, No. 213 



\begin{abstract}
During early 1991, an archaeologist from The Center for Archaeological Research (CAR), the University of Texas at San Antonio (UTSA), monitored the expansion of the Casa Rio Restaurant in downtown San Antonio. The expansion exposed, but did not damage, the foundation of the first Beckmann home constructed in 1859. Research for the property also revealed that the basement and support structures for the second Beckmann home probably exist within the parking lot immediately to the south of the expanded facility. No further historical work is required for this project but any future modification to the area must address the critical potential resources.
\end{abstract}


TABLE OF CONTENTS

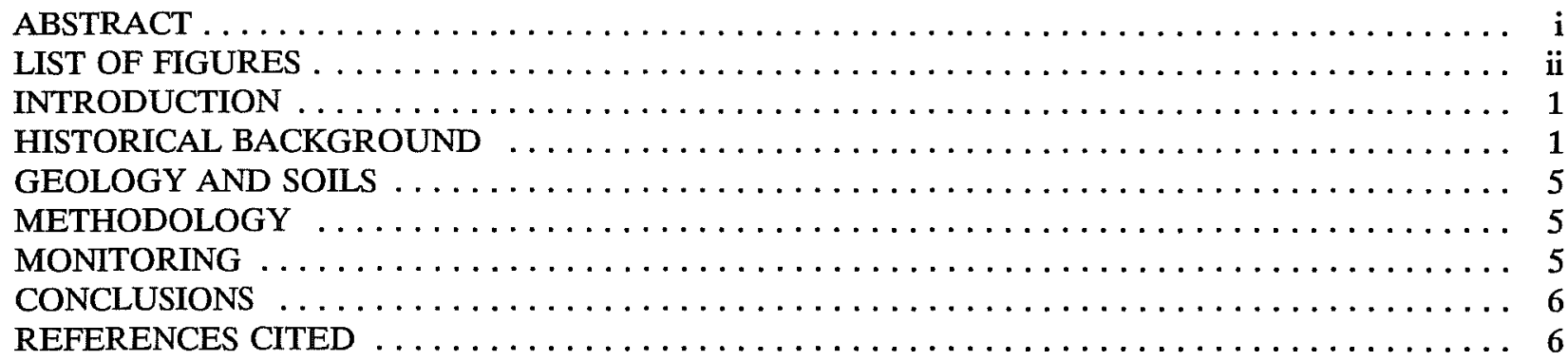

\section{LIST OF FIGURES}

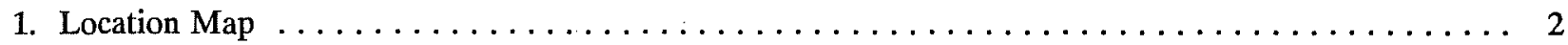

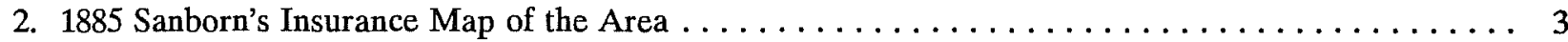




\section{INTRODUCTION}

In December of 1990, the Center for Archaeological Research, The University of Texas at San Antonio (CAR-UTSA), entered into a contract with Alamo Architects of San Antonio to perform monitoring for the Casa Rio Restaurant expansion project on the Riverwalk in downtown San Antonio. The proposed expansion affected two areas to the west of the restaurant in an area that is now a parking lot and an alley behind Shilo's Delicatessen on Commerce Street (Fig. 1). In mid-January, the Center was informed that the work was in progress, and I. Waynne Cox began monitoring operations. Monitoring continued throughout the initial excavation until Phase I was completed. At that time it was determined that the area to be developed later would contain only fill material deposited by the river, and by the construction of the Riverwalk during the late 1930s. After that point only occasional spot checks were conducted to insure that no unexpected historic materials or features were encountered. The monitoring project was done under the general supervision of Jack D. Eaton, acting director of CAR.

\section{HISTORICAL BACKGROUND}

The lots in question, located in New City Block (NCB) 159, were a portion of a larger grant of land originally owned by Ana Maria Gertrudis de los Santos Coy. Gertrudis inherited a block of property from her mother, Maria Curbelo de los Santos Coy, on November 3, 1784 (Chabot 1937:75, Spanish Records Vol.2:290). On January 25, 1831, a portion of this inheritance was purchased by "Juan" McMullen (BCDR J1:245). This property was bounded on the north by Commerce Street, on the east and south by the San Antonio River and on the west by Presa Street (Fig. 2).

John McMullen was born in Ireland in 1785 and immigrated to Baltimore, Maryland, where he met and married Esther Cummings. He entered into partnership with James McGloin, a fellow Irishman and later his son-in-law. They received an empresario contract on August 16, 1828, authorizing them to settle two hundred families along the left bank of the Nueces River. Although they were not able to fulfill the terms of the contract, they established the town of San Patricio on October 24, 1831 (Webb 1952 Vol. II:122). After the battle for Texas Independence from Mexico, McMullen moved to San Antonio and constructed a home on his land at the corner of Presa and "Calabosa" (Market Street), site of the present Hertzburg Circus Museum (Chabot 1937:275). In 1839, he served as a city alderman under Mayor Samuel Maverick. His wife, Esther, died on November 9, 1846. In the early morning hours of January 21, 1853, John McMullen was found murdered in his home, a victim of an unknown assassin. Robbery was the suspected motive for the crime, since it was known that he kept a large amount of cash in an old style safe in the home. At the time of his death he had reached the age of sixty-eight (Barnes 1910:242, Oberste 1973:283, Probate Records Book C "Blue" 170-175).

McMullen died leaving no immediate heirs; therefore, the estate passed to his brothers and sisters in Pennsylvania; Anthony, James, Neal, Ann McMullen and Margaret McMullen Egan. The town lot..."fronting 77 varas (213.88 feet) on Commerce Street, west from the River to its western boundary, thence south 156 varas (433.32 feet) to the San Antonio River...to place of beginning". This was purchased at its evaluated price of $\$ 10,000$, by their attorney Jacob Waelder, on May 23, 1854 (Probate Record Book C "Blue":208,295, Book D "Red":156, BCDR M1:284).

Frederick Jacob Waelder, son of Frederick and Sophia Bonnert Waelder, was born in Meisenheim, Hesse Homburg, Germany, on May 17, 1820. Due to his father's Republican sympathies, the family emigrated to Pennsylvania in 1833 where Jacob entered school. In 1838, he returned to Germany to complete his education. In 1841, he again returned to Pennsylvania and was admitted to the bar in 1845. He served in the Mexican War and rose to the position of aide-de-camp and acting Adjutant General. After the war, he returned to Pennsylvania and, in 1848, married Elizabeth Pool Lamb. Because of his wife's poor health, they moved to San Antonio in 1852. It was probably because of his Pennsylvania connections that he was selected attorney for the McMullen family that led to his purchase of the Commerce Street property. During the Civil War he held a Major's commission in the Confederate Army. After the death of his first wife, he married, in 1870, Ada Bradley 
COMMERCE STREET

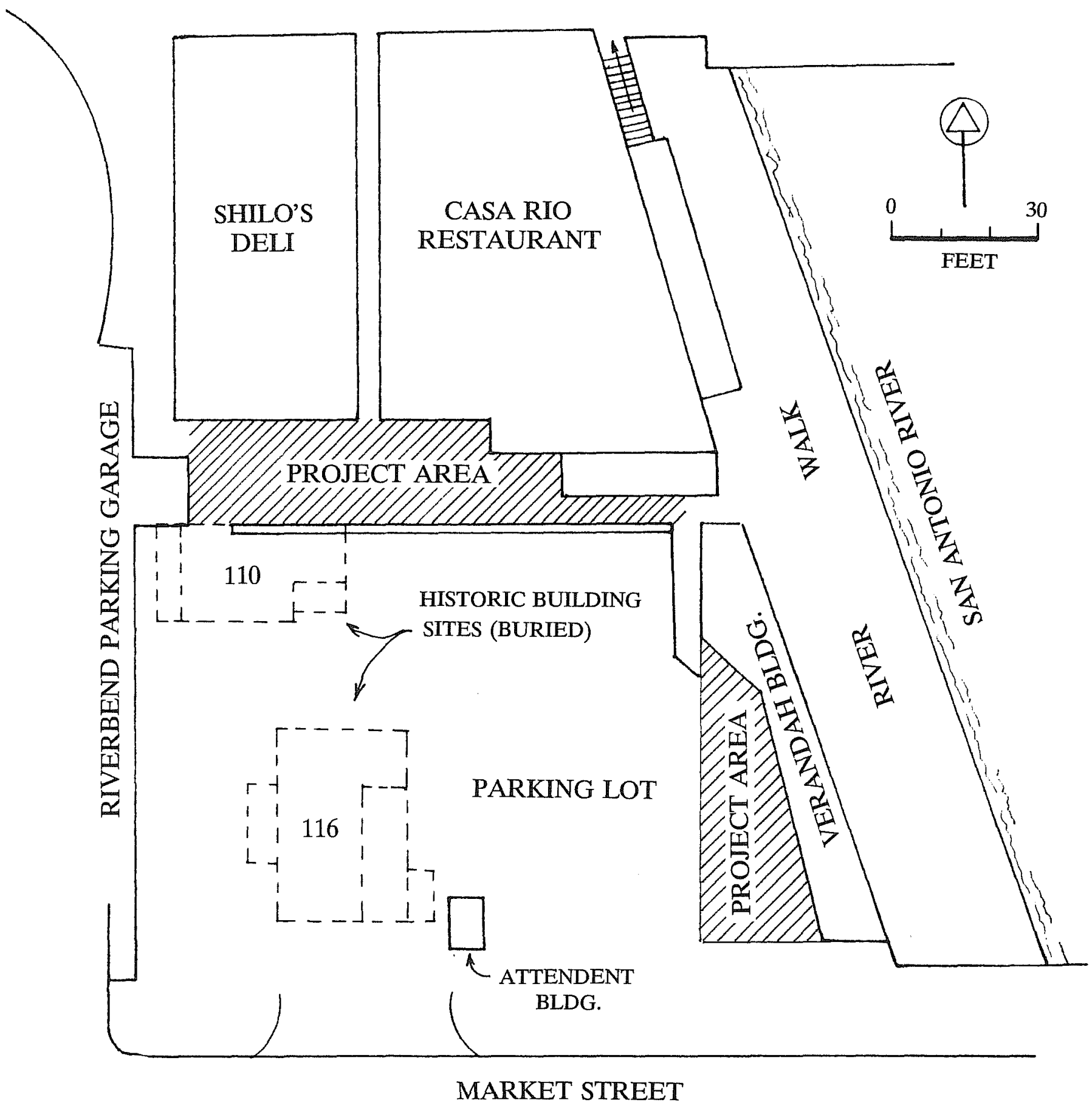

Figure 1. Location Map. Indicated are the Historic Building Sites. 


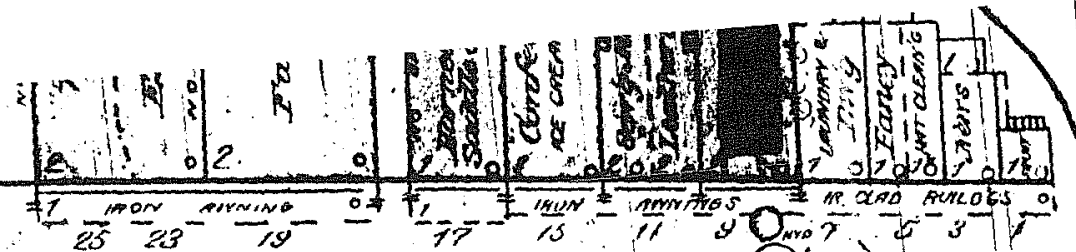

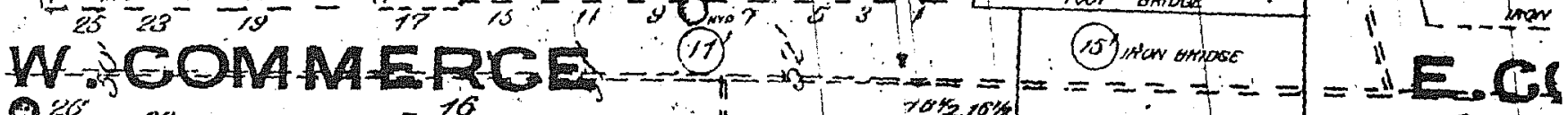
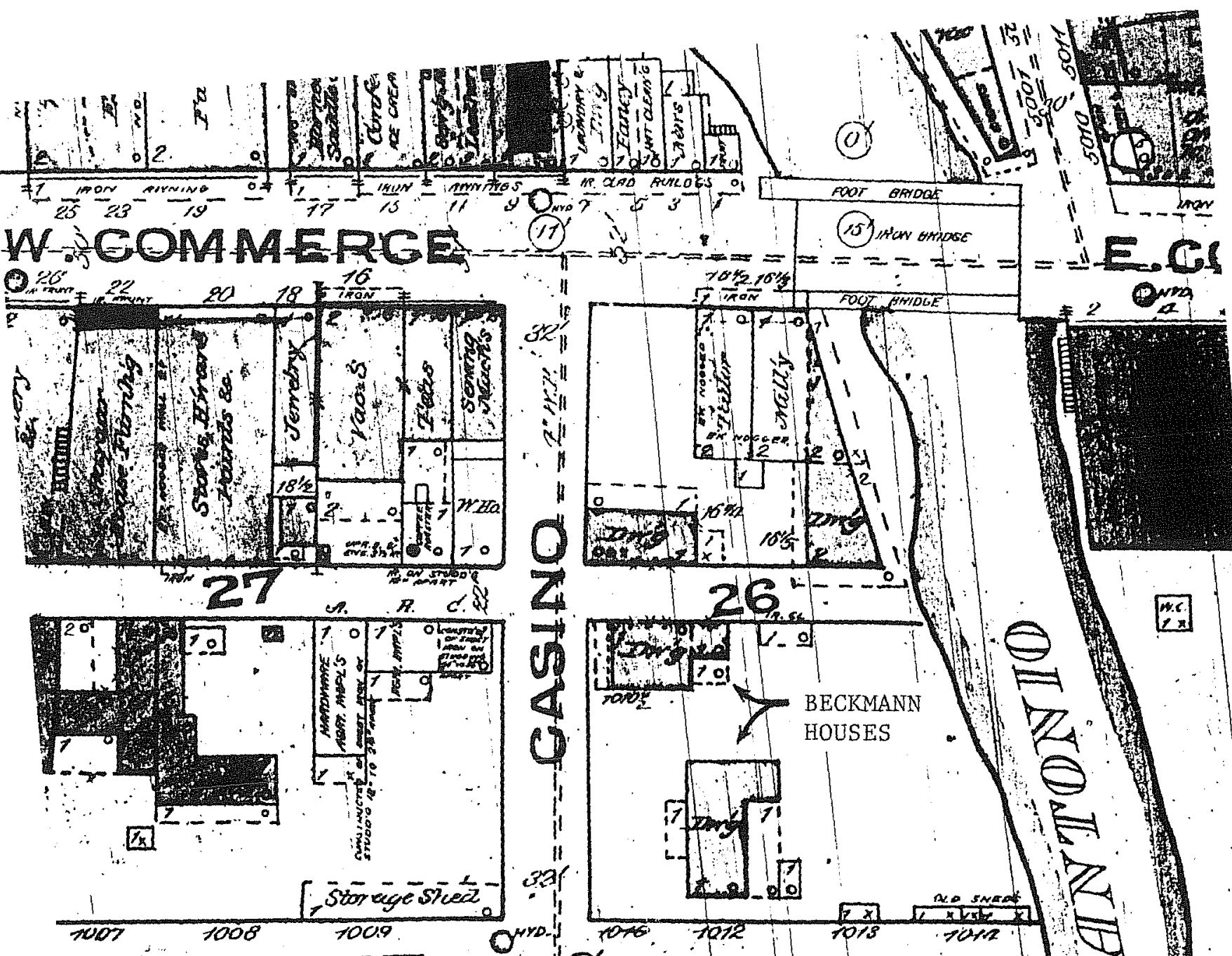

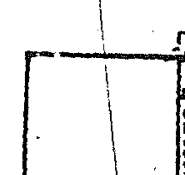
$\sqrt{x+x_{0}=0}$

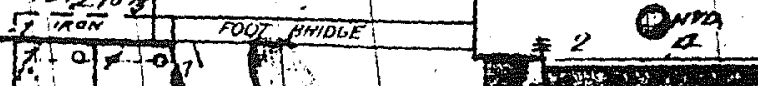

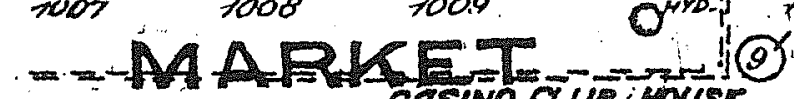
19 20, 1020 CASINO Q UB 70 USE: (1)

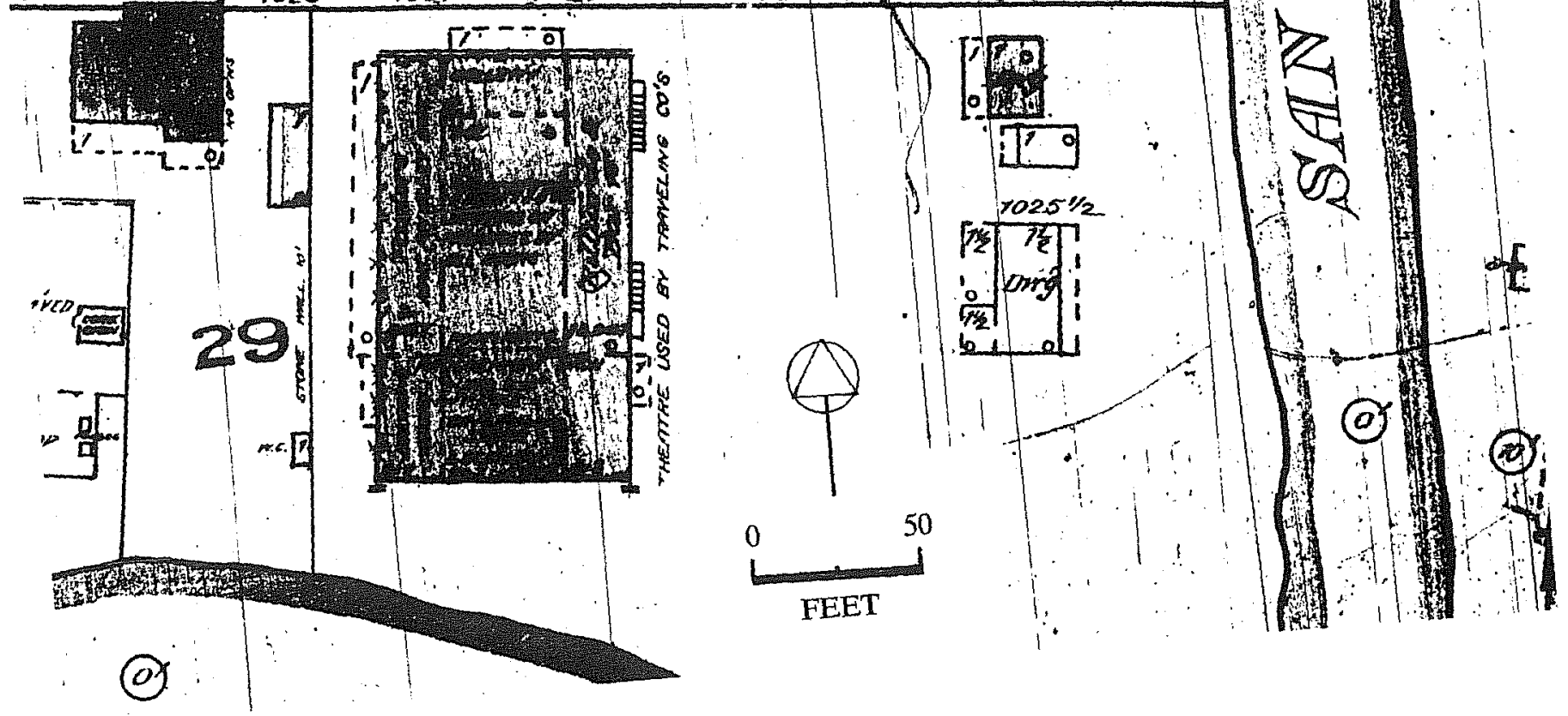


Maverick, the widow of Lewis A. Maverick. He was the first president of the Casino Association and sold them the land from the McMullen property which became the site of Casino Hall. Waelder died at White Sulpher Springs, Virginia on August 28, 1887, at age sixty-seven, and was buried with high honors in San Antonio (Chabot 1937:297-99, Webb 1952 Vol II:849-50).

After Waelder acquired the McMullen property, he had it surveyed and subdivided by William Thielopape, establishing a central street connecting Commerce and Market Street which would become Casino Street. He also provided for an alley, running east to west, through the middle of the property, which later became NCB 159 and 160 (BCDR M1:556). In December of 1854, Waelder conveyed the northeastern corner of the property along the San Antonio River to Thomas Wren and Joseph Malloy (BCDR M1:556). In September of 1857, Waelder sold the lot on the northwest corner of Casino and Commerce Streets to John C. Beckmann, who established his blacksmith shop at that location (BCDR R1:62).

The Wren and Malloy property (northern portion of NCB 159) in 1854, was fully acquired by Thomas Wren in 1855 (BCDR N1:350). The property began at the southwest corner of the Commerce Street Bridge at the river and ran along the south side of the street for 31 varas (81 feet) to a "street 12 varas wide (Casino Street) thence along the street south 100 feet to the corner of an alley, thence 31 varas along said alley to the San Antonio River, thence along said river to a corner near the bridge" (BCDR M1:556). Commerce Street was the only east-west thoroughfare in the city at that time, and as such developed primarily as mercantile business establishments. All of the residences on the block faced Casino Street. Wren constructed a home on Casino Street (108 Casino) in 1856 which served as his widows home until 1887 (CD 1877-1878,1887-1888). In 1857, Wren sold the northeastern corner of the block to A.K.and W. C. Tynan (BCDR P2:344).

John Conrad Beckmann was born in Ruelle, Westphalia, on June 13, 1815. He came to New York in 1839, and upon his return to Europe married Regina Mueller of Zurich, Switzerland. They returned to New York and relocated to New Orleans in 1841, and in 1846, moved to San Antonio. Beckmann, a talented blacksmith, was first employed by the United States Army, then stationed at the Alamo, and he constructed his first home near there on Crockett Street (San Antonio Express 1907, Chabot 1937:375).

In 1859, Beckmann purchased two additional lots (NCB 159, lots 6 and 7) from Waelder and constructed a home on lot 6, the southeast corner of Casino and the alley that ran through the middle of the tract $(B C D R$ U1:184, Sanborn 1885). This was a small vernacular home (110 Casino), approximately 25 by 25 feet, constructed of soft limestone (Sanborn 1885). Shortly thereafter, he reputedly sold the home to an army officer for "...a very good price", and built a larger home on the adjacent lot (Lot7); however, a search of deed records shows no indication of this transaction, although in 1877 the structure was occupied by Lieutenant Charles E. Bottsford, U.S.A. It is likely that the home was leased by Beckmann for a number of years (Chabot 1937:375, City Directory 1877-78).

The second Beckmann home (116 Casino) was constructed soon after the first home but was considerably larger, measuring approximately 44 feet by 35 feet with a "half basement" below the main structure. The main floor would have served as the family and public area while the floor below would have housed the individual living quarters. The home was set back 35 feet from, and facing toward Casino Street, and 10 feet north of what would later become the extension of Market Street to the river.

Vinton Lee James described the area as he remembered it shortly after the Civil War:

(Commerce Street) "Across the river, in a house raised on pilings, lived the Widow Wren. She was a laundress and had two sons, Andrew, and Tom, who worked for the hardware firm of Leroux \& Cosgrove. Across Casino Street was the blacksmith shop of Conrad Beckmann." (Market Street) "Adjacent was the lot owned by Conrad Beckmann, whose blacksmith shop fronted on Commerce Street. He had a pretty rock residence at the corner of Market and Casino Street, and his lot extended to the San Antonio River." (James 1938:140,149) 
As late as 1873 , the only structures on the block were the Wren home and the two Beckmann houses. However, by 1885 two commercial iron fronted and brick-nogged structures had been erected on the Tynan property, probably constructed about 1881 (Koch 1873 , CD 1879-80, 1881-82, Sanborn 1885). In July of 1885, Mrs. Wren leased the Commerce Street property to the north of her home to Valentine Lorra to erect "...a store according to plans...prepared by Charles Buchel, architect..." (BCDR 42:366). Lorra's merchant tailor shop is listed in the city directory in 1887 (CD 1887-88). In 1897, the original Beckmann property (110 Casino) was occupied by Mrs. B. Diehl (widow of D. B.) as her residence and dress shop, and Lorra's, has become the J. Lobert tailor shop (CD 1897-98). John Beckmann occupied the home at 116 Casino until shortly before his death on April 12, 1907 (San Antonio Express April 13,1907). By 1910, the house at 108 Casino had been incorporated into the Commerce street address, the house at 110 Casino was sewing machine sales, and 116 was Mrs. Alice Howard's

Rooming House (CD 1910-11). The Beckmann home was razed in 1926 and 110 Casino in 1929, and a parking lot was constructed on the site shortly thereafter (CD 1926, 1927-28, 1929-30).

In 1939, the Riverwalk Beautification project was begun and the portion of the lots near the river was greatly altered by construction and fill (Schuchard 1951:75). In May of 1944, Alfred F. Beyers acquired lot A2 from William J. Lyons (this was the structure just to the east of the Kate Tynan and Hugh Rice property) and opened an appliance store on Commerce Street (BCDR 2057:555). Two years later he expanded the store with the purchase of the lot to his east on the west bank of the San Antonio River (BCDR 2211:228). As he cleared the silt from the basement of the new building he envisioned a new enterprise on the riverfront; he purchased the lot to the south eight months later and opened the first restaurant on the river (BCDR 229:429). He was the first to have the vision that would become the leading tourist attraction some three decades later, San Antonio's Riverwalk. He also pioneered the river barges for dining on the river. His first effort cost $\$ 10,000$ but the barge sank on the first launching (San Antonio Express: February 11, 1974).

\section{GEOLOGY AND SOILS}

The site under study is located on the western bank of the San Antonio River. The soils of the area are of the Trinity-Frio Association; deep, calcarious clays of bottom lands and terraces, a dark black clay loam (Taylor, Hailey, and Richmond 1966). The western bank of the river has been eroded by stream flow and flooding, and generally has been altered by the deposition of fill dirt to facilitate the construction of buildings and landscaping.

\section{METHODOLOGY}

The archaeologist monitored the project during the excavation phases of construction. Measured drawings were taken when required and photographs were taken when appropriate. Field notes, drawings and photographs compiled during the operations are on file at the CAR-UTSA. No artifacts were encountered. Field measurements were taken in feet and inches, since all construction and available map were in that scale.

\section{MONITORING}

Monitoring was first conducted on the area of the parking lot behind the Verandah Building, which consisted of two shallow trenches to support grade beams for the extension of the existing building. The primary concentration for monitoring was the deep excavation on the western end of the alley behind the buildings facing Commerce Street and the parking lot. In the area immediately south of Shilo's Delicatessen, soil was excavated from the entire alley space to a depth of approximately eight feet. This exposed the northern face of the foundation of the first Beckmann home (110 Casino), which was aligned to the lot line adjacent to the alley. The foundation was constructed of ashlar-dressed limestone, which deepened with the slope toward the river. To the east of the foundation, the former backyard was filled by the embankment created during the Riverwalk 
Beautification Project. During this portion of the project, the basement area under the delicatessen was open and exposed the original foundations of the building which faced Commerce Street prior to its widening in 1917. These were also of ashlar-dressed limestone. Monitoring was reduced at this point when it was determined that the area east to the river was late deposition from recent improvements along the river frontage.

\section{CONCLUSIONS}

While the development excavation had no major impact on any cultural resources, they did expose the foundations of the first Beckmann home, constructed in 1859, and indicated that a substantial portion of that property remains intact. The second home (116 Casino) stood until 1926, when the property was converted into a parking lot. The foundation of the house probably still exists below the surface. Since this house contained a half-basement, there is undoubtedly a great deal of material evidence protected under the surface of the lot. If any further development is considered within this area, archaeological investigations should be conducted in order to document these two unique structures and associated deposits of the city's history from the mid-1800s. Since developments have not impacted the buried historical features, no further investigations are recommended in association with present expansion of the Casa Rio Restaurant.

\section{REFERENCES CITED}

Barnes, C. $M$.

1910 Combats and Conquest of Immortal Heros Sung In Song and Told In Story. Guessaz and Ferlet, San Antonio, Texas.

Bexar County Deed Records $(B C D R)$

Office of the County Clerk, Bexar County Courthouse, San Antonio, Texas.

Chabot, F. C.

1937 With the Makers of San Antonio. Privately published, San Antonio, Texas.

City Directories (CD)

1877- Microfilm on file, John Peace Library, The University of Texas at San Antonio, San 1934 Antonio, Texas.

James, V. L.

1938 Frontier and Pioneer Recollections of Early Days in San Antonio and West Texas. Artes Graficas, San Antonio, Texas.

Koch, A.

1873 Bird's Eye View of San Antonio.

Oberste, W. H.

1973 Texas Irish Empresarios and Their Colonies. Von Boeckmann-Jones, Austin, Texas. 
Probate Records

Wills and Probate, Bexar County Courthouse, San Antonio, Texas.

Sanborns Insurance Maps

1885- Microfilm on file, John Peace Library, The University of Texas at San Antonio, San 1951 Antonio, Texas.

San Antonio Express Newspaper

1907 "Death Claimes One of the City's Aged Pioneers", April 13.

1974 "River Ramblings", February 11.

Schuchard, E.

1951 100th Anniversary Pioneer Flour Mills, San Antonio, Texas, 1851-1951. Naylor Company, San Antonio, Texas.

Taylor, F. B., R. B. Hailey, and D. L. Richmond

1966 Soil Survey, Bexar County, Texas. U.S. Department of Agriculture, Soil Conservation Service, in Cooperation with Texas Agricultural Experiment Station, Series 1962 (12).

Webb, W. P. (editor)

1952 The Handbook of Texas. Two Volumes. Texas State Historical Association, Austin, Texas. 
